$\mathrm{UH}$

iti

Universität Hamburg

DER FORSCHUNG । DER LEHRE । DER BILDUNG
Faculty Economics and Social Sciences Chair for Economic Policy

WOLFGANG MAENNIG / FELIX RICHTER

EXPORTS AND OLYMPIC GAMES:

IS THERE A SIGNAL EFFECT?

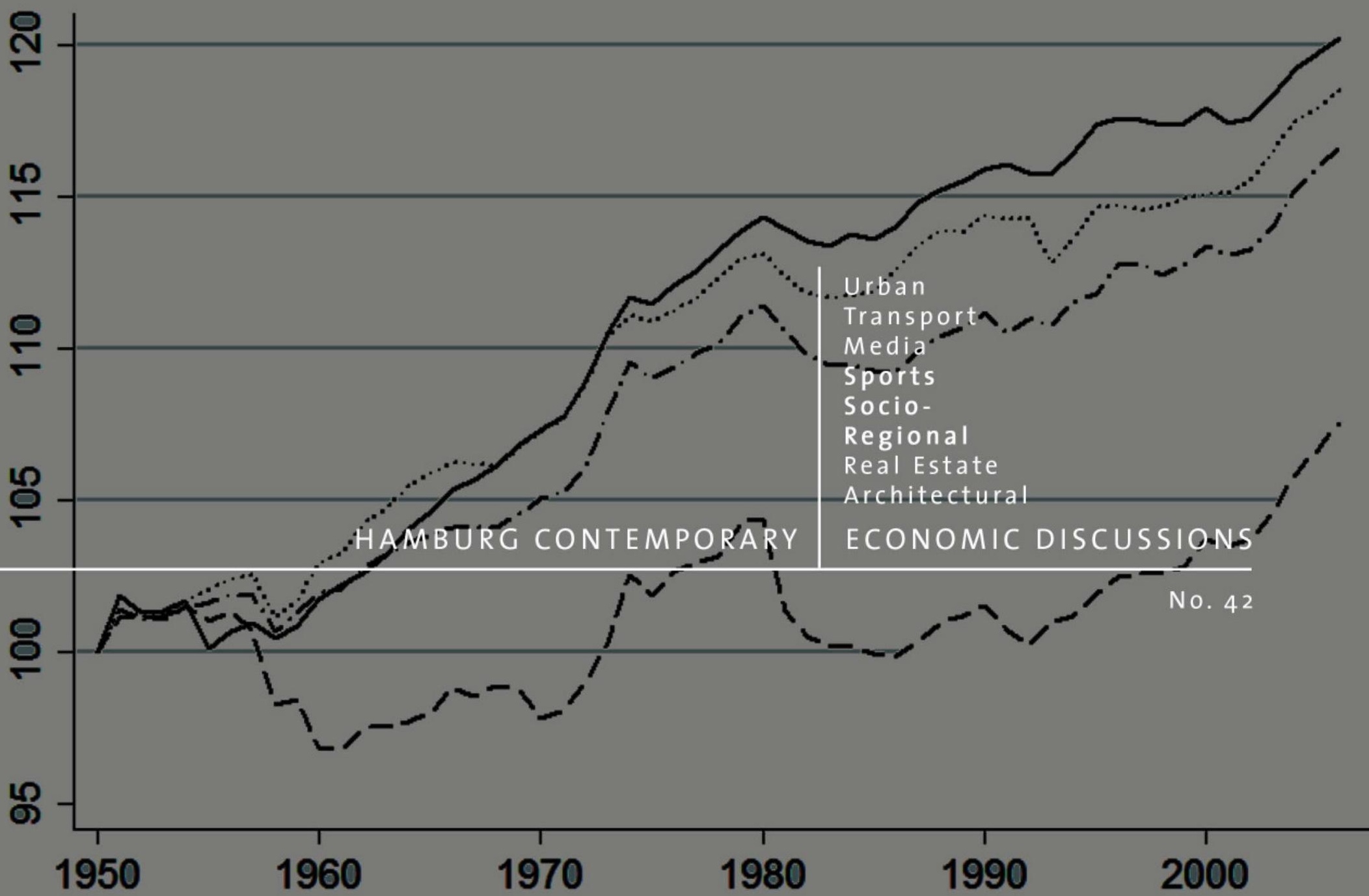


Hamburg Contemporary Economic Discussions

University of Hamburg

Faculty Economics and Social Science

Chair for Economic Policy

Von-Melle-Park 5

D-20146 Hamburg | Germany

Tel $+494042838-4622$

$\mathrm{Fax}+494042838-6251$

http://www.uni-hamburg.de/economicpolicy/

Editor: Wolfgang Maennig

Wolfgang Maennig

University of Hamburg

Faculty Economics and Social Science

Chair for Economic Policy

Von-Melle-Park 5

D-20146 Hamburg | Germany

Tel $+494042838-4622$

Fax $+494042838-6251$

wolfgang.maennig@wiso.uni-hamburg.de

Felix Richter

University of Hamburg

Faculty Economics and Social Science

Chair for Economic Policy

Von-Melle-Park 5

D-20146 Hamburg | Germany

Tel $+494042838-4628$

Fax $+494042838-6251$

Felix.richter@wiso.uni-hamburg.de

ISSN 1865 - 2441 (Print)

ISSN 1865 - 7133 (Online)

ISBN $978-3-940369-98-7$ (Print)

ISBN $978-3-940369-99-4$ (Online) 


\section{Exports and Olympic Games: Is there a Signal Effect?}

Abstract: Rose \& Spiegel (2011) find that Olympic Games host countries experience significant positive, lasting effects on exports. They interpret their results as an indication that countries use the hosting of such events to signal openness and competitiveness. We challenge these empirical findings on the grounds that a comparison of structurally different and non-matching groups of countries might suffer from a selection bias. We demonstrate that with an appropriate matching and treatment methodology, the significant Olympic effect disappears.

Keywords: Export, Olympic Games, International Trade, Treatment, Matching JEL classification: F1, L83

Version: January 2012

Rose \& Spiegel ${ }^{1}$ (RS; 2011) find that Olympic Games host countries experience significant positive, lasting effects on exports. Their results do not only hold for the actual hosts but also for countries that unsuccessfully bid for the Olympic Games. RS interpret their results as an indication that countries use such events to signal openness and economic competitiveness (i.e., a "signal effect").

We challenge the empirical findings of RS because they compare Olympic nations such as the US, Japan, Germany, Canada, Italy, Spain, and Australia, which have been among the leading export nations for centuries, to all other nations. Their comparison of structurally different, non-matching groups might suffer from a selection bias. We demonstrate that with an appropriately applied matching and treatment methodology, the RS Olympic export effect disappears.

To illustrate the structural differences between the subsamples, Figure 1 displays indices $(1950=100)$ of the logarithms of real exports. The solid line depicts the average exports of the summer Olympics host countries, which clearly outper-

\footnotetext{
${ }^{1}$ We thank Andrew K. Rose for providing the data as well as the STATA do-file for the base case regressions.
} 
forms the dashed line depicting the average exports of non-hosts. ${ }^{2}$ The dotted line shows the average exports of the OECD member states of 2006, excluding Olympic hosts. Note that the export development of the founding members of the OECD (1961) does not significantly differ. ${ }^{3}$

\section{Fig. 1 Indexed Real Log Exports.}

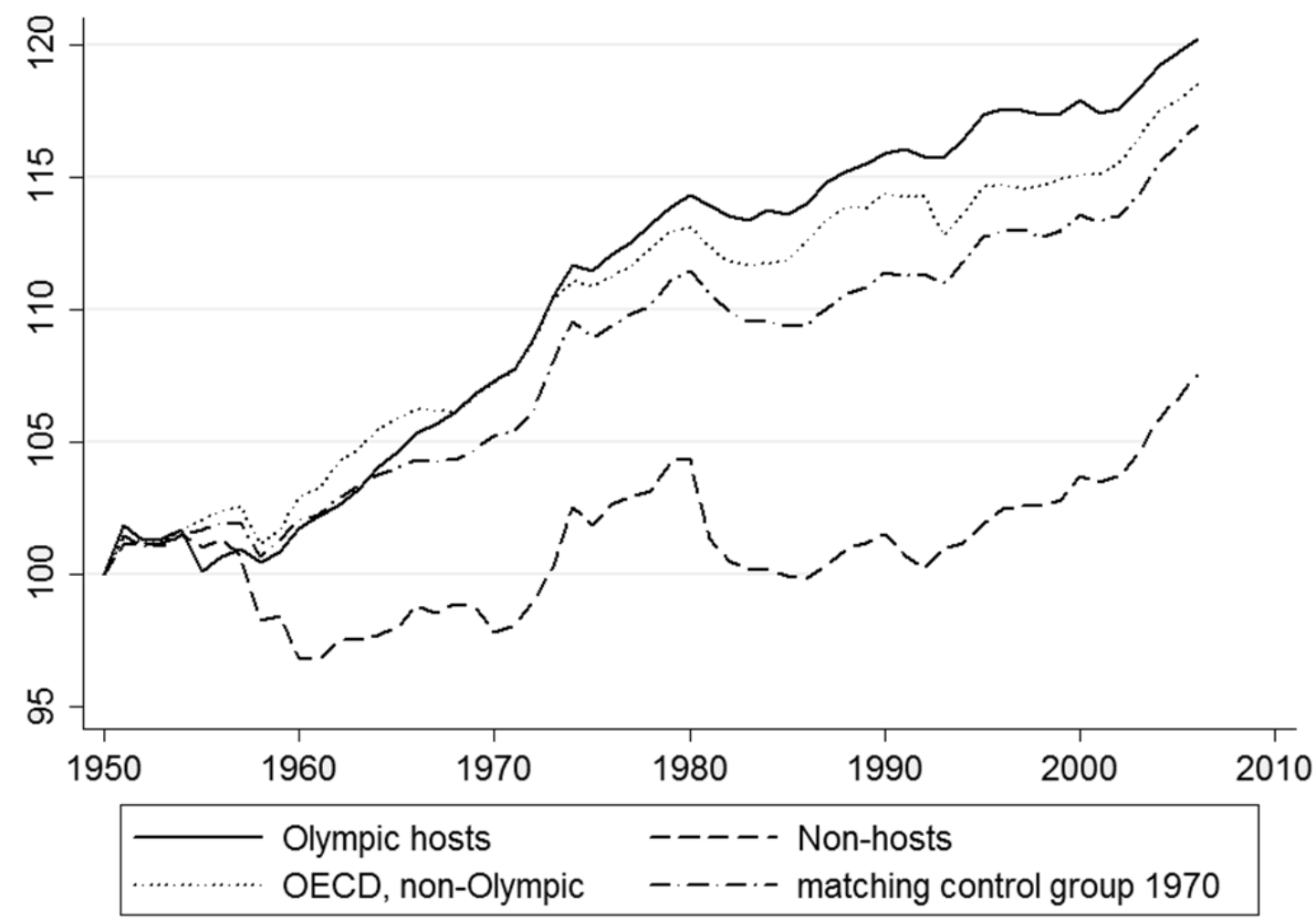

Overall, it seems plausible that Olympic host countries are structurally different from the majority of the rest of the world. To overcome this problem, we employ the matching strategy of Rosenbaum \& Rubin (1983) and estimate propensity scores, i.e. the probability of being part of a treatment group given a set of covariates. We use these estimations to systematically discriminate between Summer Olympic Games host countries (i.e., the treatment group) and non-host countries (i.e., the control group). Only countries that are otherwise structurally similar are

\footnotetext{
${ }^{2}$ As in RS, we focus our analysis on the Summer Olympic Games.

${ }^{3}$ Details are available from the authors upon request.
} 
included in the subsequent analysis. The covariates included in the propensity score estimation should affect both the outcome variable (i.e., exports) and participation in the treatment (i.e., Olympic hosts), and they should either be measured before the treatment or be time-invariant (Caliendo \& Kopeinig, 2008, p. 38). Additionally, the explanatory power of the covariates cannot be too high; matching would not be possible if these covariates perfectly predicted the assignment into the treatment or the control group (Heckmann et al., 1997, p. 637). In our case, we aggregate the RS data to obtain a single export observation for each country $i$ in year $t$. We estimate the propensity scores using the logs of both output and the population of the exporting country as covariates, fulfilling the balancing property (Becker \& Ichino, 2002). ${ }^{4}$

We first estimate propensity scores for 1950; this is the first year of the RS sample, which ranges from 1950 to 2006 . This is also before the competition dates of the first Olympic Games included in the RS investigation (Helsinki, 1952). Thus, no treatment effects should be incorporated. In the 1950 dataset, values for four Olympic hosts are missing (namely, USSR, Germany, Korea, and Greece), and the number of available non-host countries is 44 . Nineteen countries fulfill our common support condition, including the eight Olympic host countries. ${ }^{5}$ We repeat the procedure for two further reference years, where data on more countries are available. For 1970, there are observations for all hosts except for the USSR. The non-host group includes 106 countries, and 34 countries fulfill the common support condition. For 2000, data on all hosts are available. In that year, the non-host

\footnotetext{
${ }^{4}$ RS also apply a matching strategy to evaluate the robustness of their results; however, their log file indicates that their covariates are not balanced.

${ }^{5}$ The common support region is [0.103; 0.946] for the 1950 subsample, [0.069; 0.953] for the 1970 subsample, and [0.056; 0.991] for the 2000 subsample.
} 
group consists of 163 countries, while the common support condition is fulfilled by 37 countries. ${ }^{6}$

Apart from restricting our analysis to different subsamples of matching countries, we use the same investigation strategy as RS by employing an augmented version of the gravity model. Using RS's dataset of single observations for each country i's exports to country $j$ at each year $t$, we regress the logs of distance and output, an additional set of covariates, and an Olympic effect variable on the logarithms of exports of the country. The covariates include the log of the populations of both countries and a set of dummy variables that control, among other things, for common borders, common language, regional trade agreements, and common currency. The Olympic effect variable is a dummy variable that takes a value of one for the exporting country starting in the year it hosted the Olympic Games. For sensitivity analysis, we follow RS by alternatively estimating different combinations of year, dyadic and country-specific fixed effects, and country-specific linear time trends.

${ }^{6}$ Hosts fulfilling the common support, $\mathrm{t}=1950$ : Australia, Canada, Finland, Italy, Japan, Mexico, Spain, and the United States. Non-hosts fulfilling the common support, $t=1950$ : Austria, Brazil, Denmark, France, India, the Netherlands, New Zealand, Norway, Sweden, Switzerland, and the United Kingdom. | Additional hosts fulfilling the common support, $t=1970$ (compared to $\mathrm{t}=1950)$ : Germany, Greece and Korea. | Additional non-hosts fulfilling the common support, $t=1970$ (compared to $t=1950$ ): Argentina, Chile, Colombia, Hungary, Indonesia, Peru, Philippines, Poland, Portugal, Saudi Arabia, Turkey, and Venezuela. | Additional hosts fulfilling the common support, $\mathrm{t}=2000$ (compared to $\mathrm{t}=1950$ ): Germany, Greece, Korea, and Russia. | Additional non-hosts fulfilling the common support, $t=2000$ (compared to $t=1950)$ : Argentina, Belgium, China, Hong Kong, Indonesia, Ireland, Israel, Malaysia, Poland, Portugal, Saudi Arabia, South Africa, Singapore, Thailand, and the United Arab Emirates. 
Tab. 1 The Olympic Effect, Diverging Control Groups and Methods

\begin{tabular}{|c|c|c|c|c|c|c|c|}
\hline Specification: & $\mathrm{a}$ & $b$ & C & d & $\mathrm{e}$ & $f$ & $\mathrm{~g}$ \\
\hline 1. Rose Spiegel (2011) & $\begin{array}{l}0.33^{* *} \\
(0.04)\end{array}$ & $\begin{array}{l}0.24^{* *} \\
(0.03)\end{array}$ & $\begin{array}{l}0.30^{* *} \\
(0.04)\end{array}$ & $\begin{array}{l}0.19^{* *} \\
(0.04)\end{array}$ & $\begin{array}{l}0.16^{* *} \\
(0.04)\end{array}$ & $\begin{array}{l}0.34^{* *} \\
(0.03)\end{array}$ & $\begin{array}{l}0.35^{* *} \\
(0.04)\end{array}$ \\
\hline 2. Common Support $t=1950$ & $\begin{array}{c}-0.20^{* *} \\
(0.04)\end{array}$ & $\begin{array}{l}-0.01 \\
(0.04)\end{array}$ & $\begin{array}{c}0.01 \\
(0.04)\end{array}$ & $\begin{array}{l}0.15^{* *} \\
(0.05)\end{array}$ & $\begin{array}{c}0.07 \\
(0.04)\end{array}$ & $\begin{array}{c}-0.19 \\
-{ }^{\circ}\end{array}$ & $\begin{array}{c}0.01 \\
(0.04)\end{array}$ \\
\hline 3. Common Support $t=1970$ & $\begin{array}{c}0.01 \\
(0.04)\end{array}$ & $\begin{array}{l}-0.02 \\
(0.03)\end{array}$ & $\begin{array}{c}0.01 \\
(0.04)\end{array}$ & $\begin{array}{l}0.10^{*} \\
(0.04)\end{array}$ & $\begin{array}{c}0.04 \\
(0.04)\end{array}$ & $\begin{array}{c}0.04 \\
(0.03)\end{array}$ & $\begin{array}{c}0.03 \\
(0.04)\end{array}$ \\
\hline 4. Common Support $t=2000$ & $\begin{array}{l}-0.07 \\
(0.04)\end{array}$ & $\begin{array}{c}0 \\
(0.03)\end{array}$ & $\begin{array}{c}0.01 \\
(0.04)\end{array}$ & $\begin{array}{l}0.11^{* *} \\
(0.04)\end{array}$ & $\begin{array}{c}0.01 \\
(0.04)\end{array}$ & $\begin{array}{l}-0.03 \\
(0.03)\end{array}$ & $\begin{array}{c}0.02 \\
(0.04)\end{array}$ \\
\hline 5. OECD 2006 & $\begin{array}{l}-0.03 \\
(0.04)\end{array}$ & $\begin{array}{l}-0.08^{*} \\
(0.04)\end{array}$ & $\begin{array}{c}-0.05 \\
(0.04)\end{array}$ & $\begin{array}{c}0.06 \\
(0.04)\end{array}$ & $\begin{array}{c}-0.04 \\
(0.04)\end{array}$ & $\begin{array}{c}0 \\
(0.04)\end{array}$ & $\begin{array}{c}-0.06 \\
(0.04)\end{array}$ \\
\hline Year Effects & $x$ & $x$ & $x$ & $\mathrm{X}$ & $x$ & $x$ & \\
\hline Dyadic Fixed Effects & & $x$ & & & & & \\
\hline Exporter Fixed Effects & & & $x$ & & & & $x$ \\
\hline Importer Fixed Effects & & & $x$ & & $\mathrm{X}$ & & \\
\hline Exporter*Time Fixed Effects & & & & $\mathrm{x}$ & $x$ & & \\
\hline Importer*Time Fixed Effects & & & & & & $\mathrm{x}$ & $\mathrm{X}$ \\
\hline
\end{tabular}

Table 1 reports the regression results for the Olympic effect coefficient if we restrict the RS method to the countries that fulfill the common support condition in 1950 (row \#2), 1970 (row \#3), and 2000 (row \#4). For ease of comparison, row \#1 displays the RS results, which we were able to replicate. With the single exception of specification d (i.e., fixed-year effects and country-specific exporter trends), no significant positive effects are measurable in the different subsamples. For the sample restricted to those countries on the common support in $t=1950$ and the specifications (a) and ( $f$ ), even significant negative effects can be found. If the analysis is restricted to those countries on the common support in $t=1970$ (row \#3) and $t=2000$ (row \#4), where the data is the most complete, the majority of the effects is insignificant and around zero, with coefficients often below one standard deviation. Specification (d) is again an exception.

For readers who mistrust complex data selection methods as treatment and matching procedures, we alternatively compare the Olympic OECD countries with 
the non-Olympic OECD countries, which can be reasonably assumed to be structurally alike. Again, no significant, positive effects on exports are found (row \#5).

As mentioned above, RS find that their results do not only hold for actual hosts but also for countries that unsuccessfully bid for Olympic Games, leading them to the interpretation that countries use the Games (and similar events) to signal openness and increasing economic competitiveness ("signal effect"). ${ }^{7}$ However, when controlling for the structural (dis)similarities of countries, there is hardly any evidence for such an effect.

\footnotetext{
${ }^{7}$ We tested for bidding countries as well and did not find any systematic significant, positive effects. Details are available from the authors on request.
} 


\section{Literature}

BECKER, S. \& ICHINO, A. (2002), Estimation of Average Treatment Effects Based on Propensity Scores, The Stata Journal, 2(4), 358-377.

CALIENDO, M. \& KOPEINIG, S. (2008), Some practical Guidance for the Implementation of Propensity Score Matching, Journal of Economic Surveys, 22(1), 31-72.

HECKMANN, J., ICHIMURA, H. \& TODD, P. (1997), Matching as an Econometric Evaluation Estimator: Evidence from Evaluating a Job Training Programme, Review of Economic Studies, 64(4), 605-654.

ROSE, A. \& SPIEGEL, M. (2011), The Olympic Effect, The Economic Journal, 121, 652-677.

ROSENBAUM, P. \& RUBIN, D. (1983), The Central Role of the Propensity Score in

Observational Studies for Causal Effects, Biometrika, 70(1), 41-55. 


\section{Hamburg Contemporary Economic Discussions}

(Download: http://www.uni-hamburg.de/economicpolicy/discussions.html)

42

41

40

39

38

37

36

35

34

33

32

31

30

29

MAENNIG, W. / RICHTER, F.: Exports and Olympic Games: Is there a Signal Effect?, 2012

MAENNIG, W. / WILHELM, M.: Becoming (un)employed and life satisfaction: Asymmetric effects and potential omitted variable bias in empirical happiness studies, 2011

MAENNIG, W.: Monument Protection and Zoning in Germany: Regulations and Public Support from an International Perspective, 2011

BRANDT, S. / MAENNIG, W.: Perceived Externalities of Cell Phone Base Stations - The Case of Property Prices in Hamburg, Germany, 2011

MAENNIG, W. I STOBERNACK, M.: Do Men Slow Down Faster than Women?, 2010

DU PLESSIS, S. A. / MAENNIG, W.: The 2010 World Cup Highfrequency Data Economics: Effects on International Awareness and (Self-defeating) Tourism, 2010

BISCHOFF, O.: Explaining Regional Variation in Equilibrium Real Estate Prices and Income, 2010.

FEDDERSEN, A. / MAENNIG, W.: Mega-Events and Sectoral Employment: The Case of the 1996 Olympic Games, 2010.

FISCHER, J.A.V. / SOUSA-POZA, A.: The Impact of Institutions on Firms Rejuvenation Policies: Early Retirement with Severance Pay versus Simple Lay-Off. A Cross-European Analysis, 2010.

FEDDERSEN, A. / MAENNIG, W.: Sectoral Labor Market Effects of the 2006 FIFA World Cup, 2010.

AHLFELDT, G.: Blessing or curse? Appreciation, Amenities, and Resistance around the Berlin "Mediaspree", 2010.

FALCH, T. / FISCHER, J.A.V.: Public Sector Decentralization and School Performance: International Evidence, 2010.

AHLFELDT, G. / MAENNIG, W. / ÖLSCHLÄGER, M.: Lifestyles and Preferences for (Public) Goods: Professional Football in Munich, 2009.

FEDDERSEN, A. / JACOBSEN, S. / MAENNIG, W.: Sports Heroes and Mass Sports Participation - The (Double) Paradox of the "German Tennis Boom", 2009. 


\section{Hamburg Contemporary Economic Discussions}

(Download: http://www.uni-hamburg.de/economicpolicy/discussions.html)

AHLFELDT, G. / MAENNIG, W. / OSTERHEIDER, T.: Regional and sectoral effects of a common monetary policy: evidence from Euro Referenda in Denmark and Sweden, 2009.

BJФRNSKOV , C. / DREHER, A. / FISCHER, J.A.V. / SCHNELLENBACH, J.: On the Relation Between Income Inequality and Happiness: Do Fairness Perceptions Matter?, 2009.

AHLFELDT, G. / MAENNIG, W.: Impact of Non-Smoking Ordinances on Hospitality Revenues: The Case of Germany, 2009.

FEDDERSEN, A. / MAENNIG, W.: Wage and Employment Effects of the Olympic Games in Atlanta 1996 Reconsidered, 2009.

AHLFELDT, G. / FRANKE, B. / MAENNIG, W.: Terrorism and the Regional and Religious Risk Perception of Foreigners: The Case of German Tourists, 2009.

AHLFELDT, G. I WENDLAND, N.: Fifty Years of Urban Accessibility: The Impact of Urban Railway Network on the Land Gradient in Industrializing Berlin, 2008.

AHLFELDT, G. / FEDDERSEN, A.: Determinants of Spatial Weights in Spatial Wage Equations: A Sensitivity Analysis, 2008.

MAENNIG, W. / ALLERMS, S.: South Africa 2010: Economic Scope and Limits, 2008.

MAENNIG, W. / WELLBROCK, C.-M.: Sozio-ökonomische Schätzungen Olympischer Medaillengewinne: Analyse-, Prognose- und Benchmarkmöglichkeiten, 2008.

AHLFELDT, G.: The Train has Left the Station: Real Estate Price Effects of Mainline Realignment in Berlin, 2008.

MAENNIG, W. / PORSCHE, M.: The Feel-good Effect at Mega Sport Events - Recommendations for Public and Private Administration Informed by the Experience of the FIFA World Cup 2006, 2008.

AHLFELDT, G. / MAENNIG, W.: Monumental Protection: Internal and External Price Effects, 2008.

FEDDERSEN, A. / GRÖTZINGER, A. / MAENNIG, W.: New Stadia and Regional Economic Development - Evidence from FIFA World Cup 2006 Stadia, 2008.

AHLFELDT, G. / FEDDERSEN, A.: Geography of a Sports Metropolis, 2007. 


\section{Hamburg Contemporary Economic Discussions}

(Download: http://www.uni-hamburg.de/economicpolicy/discussions.html)

14
FEDDERSEN, A. / MAENNIG, W.: Arenas vs. Multifunctional Stadia Which Do Spectators Prefer?, 2007.

AHLFELDT, G.: A New Central Station for a Unified City: Predicting Impact on Property Prices for Urban Railway Network Extension, 2007.

AHLFELDT, G.: If Alonso was Right: Accessibility as Determinant for Attractiveness of Urban Location, 2007.

AHLFELDT, G., MAENNIG, W.: Assessing External Effects of City Airports: Land Values in Berlin, 2007.

MAENNIG, W.: One Year Later: A Re-appraisal of the Economics of the 2006 Soccer World Cup, 2007.

HAGN, F. / MAENNIG, W.: Employment Effects of the World Cup 1974 in Germany.

HAGN, F. / MAENNIG W.: Labour Market Effects of the 2006 Soccer World Cup in Germany, 2007.

JASMAND, S. I MAENNIG, W.: Regional Income and Employment Effects of the 1972 Munich Olympic Summer Games, 2007.

DUST, L. / MAENNIG, W.: Shrinking and Growing Metropolitan Areas - Asymmetric Real Estate Price Reactions? The Case of German Single-family Houses, 2007.

HEYNE, M. / MAENNIG, W. / SUESSMUTH, B.: Mega-sporting Events as Experience Goods, 2007.

DU PLESSIS, S. I MAENNIG, W.: World Cup 2010: South African Economic Perspectives and Policy Challenges Informed by the Experience of Germany 2006, 2007.

AHLFELDT, G. / MAENNIG, W.: The Impact of Sports Arenas on Land Values: Evidence from Berlin, 2007.

FEDDERSEN, A. / MAENNIG, W. / ZIMMERMANN, P.: How to Win the Olympic Games - The Empirics of Key Success Factors of Olympic Bids, 2007.

AHLFELDT, G. / MAENNIG, W.: The Role of Architecture on Urban Revitalization: The Case of "Olympic Arenas" in Berlin-Prenzlauer Berg, 2007. 


\section{Hamburg Contemporary Economic Discussions}

(Download: http://www.uni-hamburg.de/economicpolicy/discussions.html)

04/2006 MAENNIG, W. I SCHWARTHOFF, F.: Stadium Architecture and Regional Economic Development: International Experience and the Plans of Durban, October 2006.

03/2006 FEDDERSEN, A. / VÖPEL, H.: Staatliche Hilfen für Profifußballclubs in finanziellen Notlagen? - Die Kommunen im Konflikt zwischen Imageeffekten und Moral-Hazard-Problemen, September 2006.

02/2006 FEDDERSEN, A.: Measuring Between-season Competitive Balance with Markov Chains, July 2006.

01/2006 FEDDERSEN, A.: Economic Consequences of the UEFA Champions League for National Championships - The Case of Germany, May 2006.

04/2005 BUETTNER, N. / MAENNIG, W. / MENSSEN, M.: Zur Ableitung einfacher Multiplikatoren für die Planung von Infrastrukturkosten anhand der Aufwendungen für Sportstätten - eine Untersuchung anhand der Fußball-WM 2006, May 2005.

03/2005 SIEVERS, T.: A Vector-based Approach to Modeling Knowledge in Economics, February 2005.

02/2005 SIEVERS, T.: Information-driven Clustering - An Alternative to the Knowledge Spillover Story, February 2005.

01/2005 FEDDERSEN, A. I MAENNIG, W.: Trends in Competitive Balance: Is there Evidence for Growing Imbalance in Professional Sport Leagues?, January 2005. 


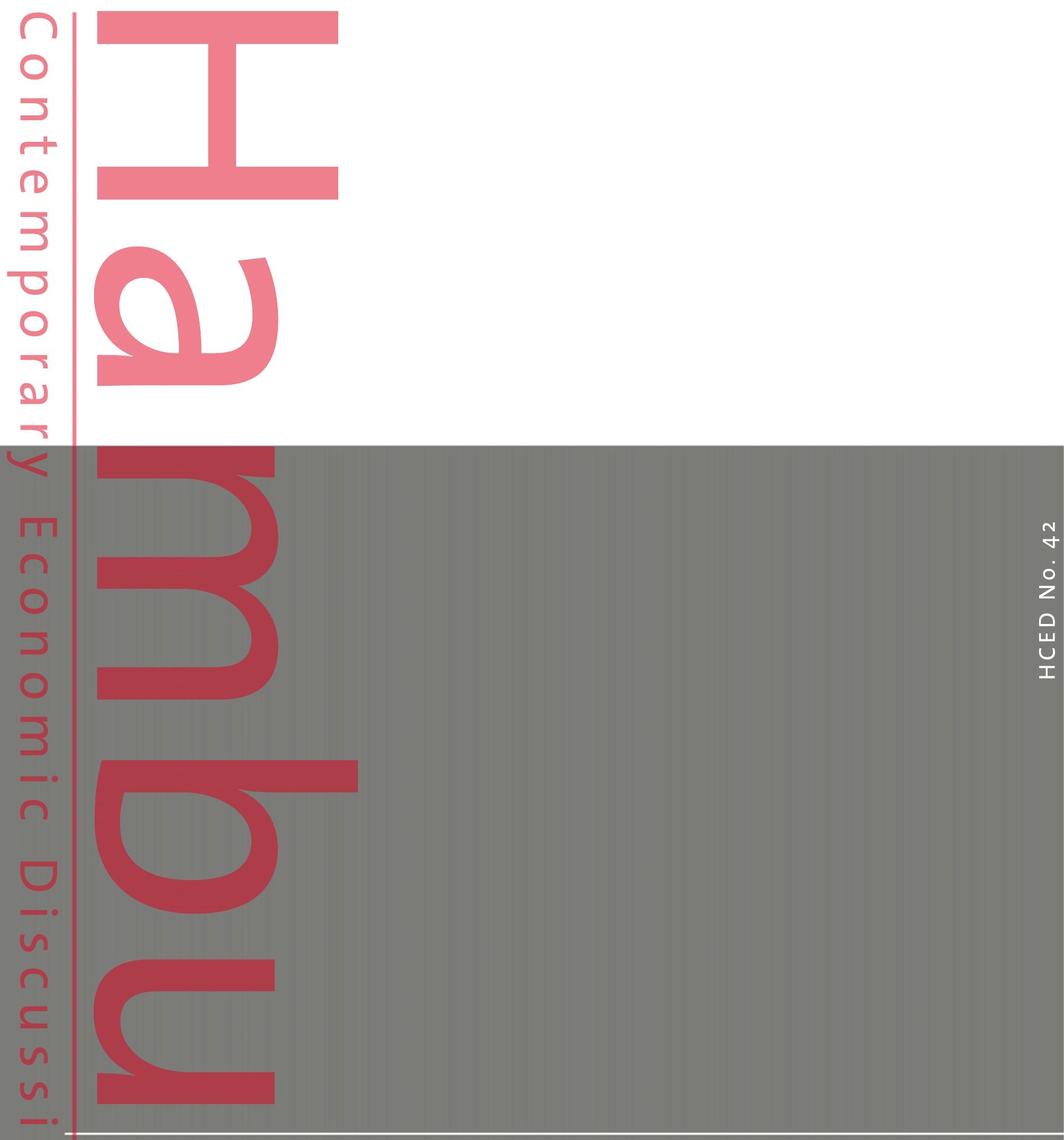

ISSN 1865-2441 (PRINT) ISSN $1865-7133$ (ONLINE)

ISBN 978-3-940369-98-7(PRINT) ISBN $978-3-940369-99-4$ (ONLINE) 